\title{
拘束鋼製せん断パネルの終局耐力と変形性能に関する研究 STUDY ON ULTIMATE STRENGTH AND DEFORMATION CAPACITY OF CONFINED STEEL PANELS
}

\author{
竹内 崇*1, 孫玉平*2 \\ Takashi TAKEUCHI and Yuping SUN
}

\begin{abstract}
This paper investigated experimentally the hysteretic behavior of steel panels confined by two pieces of polypropylene plates and bolts. The steel panels confined by polypropylene plates with thickness enough to prevent the panel from out-of-plane buckling exhibited high lateral resistance and sound energy absorption performance until the drift angle of $0.07 \mathrm{rad}$. Furthermore, methods to evaluate ultimate strength and deformation capacity of the confined steel panels were also proposed and compared with the experimental results.
\end{abstract}

Keywords : Shear Panel, Buckling load, Cumulative plastic drift angle, Equivalent shear buckling deformation angle せん断パネル，座屈荷重，累積塑性変形角，等価せん断座屈変形角

1. はじめに

地震時の建物の応答を抑制するためには，建物に制振デバイスを 組み込み，制振構造とすることが有効であり，その中でパッシブ制 振装置の一種であるせん断パネルは建物の層間変位により鋼材を塑 性化させ地震エネルギーを吸収するもので, 安定して性能を発揮す るため，広く普及している 1)。一方，大変形時までせん断パネルが エネルギー吸収性能を維持し続けるためには, パネルが早期に座屈 しないようにパネルの面外変形を抑制する必要がある。 せん断パネ ルは，パネルの左右にフランジ，上下にエンドプレートを溶接し， さらにスチフナを溶接したものが一般的に使用されており，その性 質や評価方法に関する研究が進められてきた ${ }^{2)}$-9). 玉井, 近藤, 花 井ら 2)は，K 型ブレースを介する極低降伏点鋼正方形パネルの静的 せん断実験を行い，パネル左右辺のフランジ板にテーパを設けた鋼 板パネルを用いた場合，端部の塑性変形集中を緩和できるためパネ ルが高いエネルギー吸収性能を有することを明らかにした。また， 泉, 可児ら ${ }^{3)}$ は, 間柱の中央高さ位置のウェブに極低降伏点鋼を使 用した $\mathrm{H}$ 形鋼を高力ボルト接合してダンパー部材を形成し, 静的せ 几断実験・疲労実験を実施し, 静的せん断実験において, 幅厚比が 大きければ座屈発生時の平均せん断応力度とせん断変形角が小さく なることを示すと共に，極低降伏点鋼を用いた制振部材の制振効果 の指標となる等価粘性減衰定数などの特性を明らかにした。

以上に示すように，せん断パネル型ダンパーが構造性能的に優れ ていることが既往の研究より明らかとなっている一方で, フランジ やスチフナ等の補剛材を溶接によりパネルに取り付けるため, 溶接
加工によるコストならびに補剛材による質量の増加が伴う。そこで 著者らは, より施工性に優れたせん断パネルの開発を目標として, Fig. 1 に示すように，溶接を用いず，面外補剛材としてポリプロピ レン（以下，PP）板とボルトで鋼製パネルを拘束したせん断パネル に関する研究を行ってきた 10) 14). 本提案パネルは, スチフナ等が溶 接されないため, より軽量で，パネルの力学性状の評価がより容易 である，補剛材については，比較的安価で入手しや寸く，弾性域が 広く，延性に富むPP 板を使用する。鋼板を面外補剛材で両側から 挟み拘束する手法として, 日高ら, 伊藤ら 15) 18) は構造用合板で面外 補剛されたスリット入り鋼板耐震壁に関する研究を行っており，一 般的に実用化されている耐震壁と同等の性能を発揮することを示し た。本提案せん断パネルは，鋼板を面外補剛材で両側から挟み拘束 することで, 鋼板の座屈を抑制し, 高いエネルギー吸収性能を発揮 することを期待したものである。これまでの研究で，本提案せん断 パネルの履歴特性ならびに $\mathrm{PP}$ 板厚の影響を実験的に調べ，その結 果，適切な面外剛性を有するように PP 板厚を決定すれば，鋼板パ ネルが最大耐力に達するまで面外変形をほとんど生じず，優れたエ

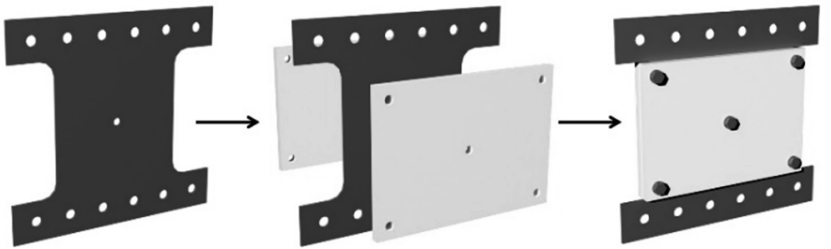

Fig.1 Concept of the confined steel panel
*1 神戸大学大学院工学研究科 助教 $\cdot$ 博士 (工学)

*2 神戸大学大学院工学研究科 教授. 工博
Assist. Prof., Graduate School of Engineering, Kobe University, Dr.Eng. Prof., Graduate School of Engineering, Kobe University, Dr.Eng. 
ネルギー吸収性能を発揮できることが明らかになっている 10) 14).

本提案パネルを設計する上では，パネルの保有する耐力と変形性 能を正しく評価する必要がある. 耐力の評価については，鋼製パネ ルが保有する最大限の耐力を発揮した際の「最大耐力」と, 後半の 座屈によってパネルの耐力が決定した際の「座屈耐力」の 2 つがあ り，パネルの耐力は PP 板厚による拘束力が十分な場合は前者によ って決まり，不十分な場合は後者によって決定される。言い換えれ ば，座屈耐力が最大耐力を上回るように，PP 板厚を設計すること で，パネルは座屈せず，高いエネルギー吸収性能を発揮することが 期待できる。そのためには, 最大耐力と座屈耐力を精度良く評価す る必要がある。

パネルの変形性能としては，地震時に本パネルを組み込んだ骨組 に生じる最大変形量や累積変形量に対して, パネルのエネルギー吸 収性能を低下せずに維持できることが要求される。そのため，せん 断パネルの変形性能は, 繰り返し載荷下において評価される必要が あり, 既往の研究においては, 繰り返し載荷下における, せん断パ ネルの主な終局状態の判定基準および変形能力の指標が定義されて いる 19).しかしながら，指針にて定義された終局状態の判定基準， および変形能力の指標は, いずれもフランジ付のせん断パネルを対

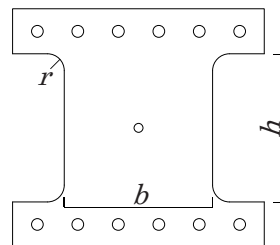

a) Steel panel

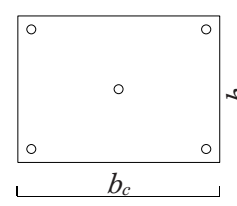

b) Confinement

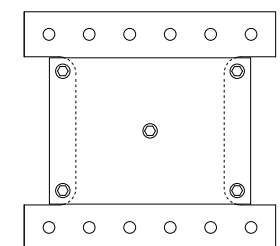

c) Specimen
Fig.2 Configuration of the specimens

Table 1 Outlines of the Specimens

\begin{tabular}{|c|c|c|c|c|c|c|c|c|c|c|c|c|c|}
\hline \multirow{3}{*}{ Series } & \multirow{3}{*}{ No } & \multirow{3}{*}{ Specimen } & \multicolumn{6}{|c|}{ Steel panel } & \multicolumn{4}{|c|}{ Polypropylene plate } & \multirow{3}{*}{$\begin{array}{l}\text { Loading } \\
\text { program }\end{array}$} \\
\hline & & & \multirow{2}{*}{ Steel } & \multirow{2}{*}{$\begin{array}{c}\text { Type of } \\
\text { Steel }\end{array}$} & \multirow{2}{*}{$\frac{t}{\mathrm{~mm}}$} & \multirow{2}{*}{$\frac{b}{\mathrm{~mm}}$} & \multirow{2}{*}{$\frac{h}{\mathrm{~mm}}$} & \multirow{2}{*}{$\frac{b / t}{-}$} & \multirow{2}{*}{$\begin{array}{c}t_{c} \\
\mathrm{~mm}\end{array}$} & \multirow{2}{*}{$\frac{b_{c}}{\mathrm{~mm}}$} & \multirow{2}{*}{$\begin{array}{c}h_{c} \\
\mathrm{~mm}\end{array}$} & \multirow{2}{*}{$\frac{E_{c}}{\mathrm{~N} / \mathrm{mm}^{2}}$} & \\
\hline & & & & & & & & & & & & & \\
\hline \multirow{16}{*}{$\mathrm{A}$} & 1 & A77P00 & \multirow{5}{*}{ PL2.3 } & \multirow{5}{*}{ SS400 } & \multirow{5}{*}{2.3} & \multirow{5}{*}{176} & \multirow{5}{*}{176} & \multirow{5}{*}{77} & - & \multirow{5}{*}{250} & \multirow{5}{*}{175} & 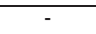 & \\
\hline & 2 & $\mathrm{~A} 77 \mathrm{P} 10$ & & & & & & & 10 & & & 1640 & \\
\hline & 3 & $\mathrm{~A} 77 \mathrm{P} 15$ & & & & & & & 15 & & & 1610 & (1) \\
\hline & 4 & $\mathrm{~A} 77 \mathrm{P} 20$ & & & & & & & 20 & & & 1580 & \\
\hline & 5 & A77P25 & & & & & & & 25 & & & 1580 & \\
\hline & 6 & A55P00 & & & & & & & - & & & - & \\
\hline & 7 & A55P05 & & & & & & & 5 & & & 2220 & \\
\hline & 8 & $\mathrm{~A} 55 \mathrm{P} 10$ & PI 20 & $\operatorname{SS} 400$ & 20 & 176 & 176 & 55 & 10 & 250 & & 1640 & \\
\hline & 9 & $\mathrm{~A} 55 \mathrm{P} 15$ & PL3.2 & $\sin 400$ & 3.2 & 176 & 176 & อร & 15 & 250 & 175 & 1610 & (1) \\
\hline & 10 & A55P20 & & & & & & & 20 & & & 1580 & \\
\hline & 11 & A55P25 & & & & & & & 25 & & & 1580 & \\
\hline & 12 & A39P00 & & & & & & & - & & & - & \\
\hline & 13 & A39P05 & & & & & & & 5 & & & 2220 & \\
\hline & 14 & A39P10 & PL4.5 & SS400 & 4.5 & 176 & 176 & 39 & 10 & 250 & 175 & 1640 & (1) \\
\hline & 15 & A39P15 & & & & & & & 15 & & & 1610 & \\
\hline & 16 & A39P20 & & & & & & & 20 & & & 1580 & \\
\hline & 17 & B55P00 & & & & & & & - & & & - & \\
\hline B & 18 & B55P20 & PL6.0-1 & SN400 & 6.0 & 330 & 330 & 55 & 20 & 448 & 326 & 1430 & (1) \\
\hline & 19 & B55P25 & & & & & & & 25 & & & 1560 & \\
\hline & 20 & $\mathrm{C} 55 \mathrm{P} 00$ & & & & & & & - & & & - & \\
\hline & 21 & C55P10 & & & & & & & 10 & & & 1380 & \\
\hline & 22 & C55P15 & PL6.0LY & LY225 & 6.0 & 330 & 330 & 55 & 15 & 448 & 326 & 1350 & (1) \\
\hline & 23 & C55P20 & & & & & & & 20 & & & 1370 & \\
\hline $\mathrm{C}$ & 24 & C55P25 & & & & & & & 25 & & & 1560 & \\
\hline & 25 & C37P00 & & & & & & & - & & & - & \\
\hline & 26 & C37P10 & PI 90 IY & IY925 & 90 & 330 & 330 & 37 & 10 & 448 & 226 & 1380 & (1) \\
\hline & 27 & C37P15 & PLY.ULY & LYZZS & 9.0 & 330 & 330 & 37 & 15 & 448 & 326 & 1350 & (1) \\
\hline & 28 & C37P20 & & & & & & & 20 & & & 1320 & \\
\hline & 29 & D55P20C1 & & & & & & & & & & 1590 & (1) \\
\hline D & 30 & D55P20C2 & PL6.0-2 & SN400 & 6.0 & 330 & 330 & 55 & 20 & 448 & 326 & 1590 & (2) \\
\hline & 31 & D55P20C3 & & & & & & & & & & 1590 & (3) \\
\hline
\end{tabular}

Note. $t$ : Thickness of steel panel, $b:$ Width of steel panel, $h:$ Height of steel panel, $t_{c}:$ Thickness of confinement, $b_{c}$ : Width of confinement, $h_{c}$ : Height of confinement, $E_{c}$ : Young's modulus of confinement.

\section{2. 拘束せん断パネルの履歴性状に関する実験 \\ 2.1 試験体概要}

本研究で対象となるせん断パネルは，鋼製パネルと，パネルの面 外変形を拘束する PP 材による拘束部で構成され，さらに鋼製パネ ルは主にエネルギー吸収をするパネル部と，載荷治具と接続するた めの接続部からなる。鋼板のパネル部を 2 枚の PP 板で両面から挟 み，ボルトで締め付けることで拘束した(Fig.2)。なお，本研究では エネルギー吸収をするパネル部の縦横比をアスペクト比と定義して おり，いずれの試験体のアスペクト比も 1.0 である。試験体は $1 / 4$ あるいは $1 / 2$ スケールの縮小試験体であり，実験変数は，鋼材種別 (普通鋼 SS400 材, SN400B 材, 低降伏点鋼 LY225 材), 鋼板厚 さ，拘束材 PP 板の厚さ，載荷プログラムの 4 種類である. 試験体 一覧を Table 1 に示す. 試験体は 4 つのシリーズ A D に分類した. シリーズ $\mathrm{A} \sim \mathrm{C}$ は鋼材種別およびパネル部寸法に応じて分類し, 各

象としたものであり，本提案パネルにそのまま適用できるものはな

本研究では, PP板とボルトで拘束されたせん断パネルについて, $\mathrm{PP}$ 板厚, 鋼材種別, 載荷プログラム等を変数とした実験的検討を行 い，軸力を受けない状況下でのせん断パネルの履歴性状を明らかに すると共に, 実験より得られた結果を元に, せん断パネルの耐力評 価法ならびに変形性能評価法を提案することを目的とする. 耐力評 価法としては，パネルの最大耐力の推定法および座屈荷重の評価法 を提案し，補剛材の設計に関する検討を行う。変形性能評価法に関 しては, 既往の変形性能評価式 19)を参考に, 本研究のせん断パネル に適用できる変形性能評価式を提案し, その妥当性を検証する.

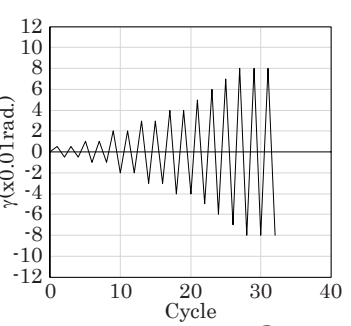

(a) Program (1)

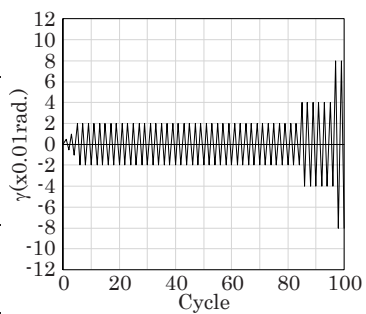

(b) Program (2)

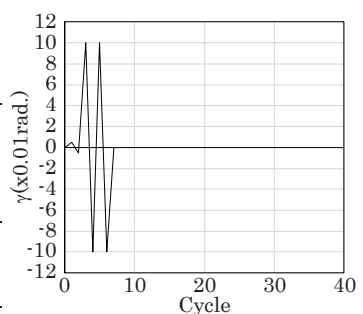

(c) Program (3)

Fig. 3 Loading Programs 
シリーズにおいて PP 板厚を変数としている. シリーズ D は, シリ ーズ B と同等のパネル寸法, 鋼材種別として, 載荷プログラム(Fig. 3)を変数としたものである. パネルは隅部にフィレット部を有して おり, その半径 (Fig.2 中の r) はシリーズ A では $20 \mathrm{~mm}$, シリー ズ B D では $37.5 \mathrm{~mm}$ である. PP 板は試験体の中央部および四隅部 でボルトにより拘束されており, シリーズ A では $14 \mathrm{~mm}$ の孔に M10 の強力ボルト（強度区分 10.9）を, シリーズ B D では $20 \mathrm{~mm}$ の 孔 に M16 の高力ボルトを通した. 拘束材と鋼板に隙間が生じないよ うに, ボルトは約 $5 \mathrm{Nm}$ のトルクで締め付けた. PP 板の引張試験で 得られたヤング係数を Table 1 中に記し, 鋼材の引張試験結果を Table 2 に示寸．ただし，引張試験の試験片は両種共に JIS Z 2201 の 5 号試験片の形状とした。 なお PP 板の引張強さは 29.1 31.9 $\mathrm{N} / \mathrm{mm}^{2}$ であった。

\section{2 載荷方法}

載荷装置を Fig. 4 に示す. パネルが軸力を負担しない状態で, 上

Table 2 Mechanical Properties of the Steels used

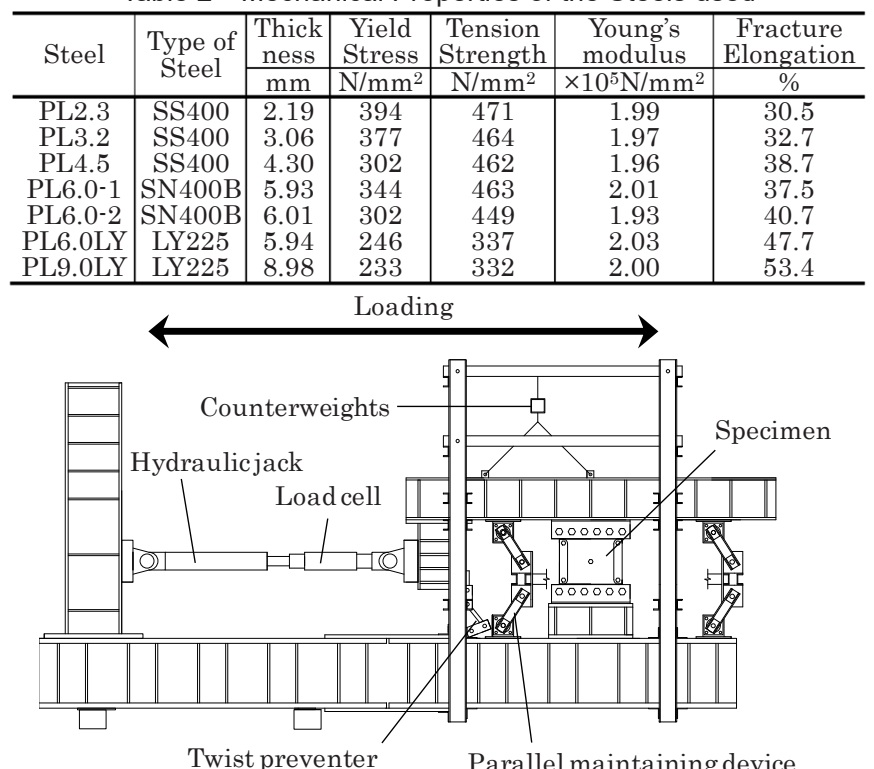

Twist preventer Parallel maintaining device Fig. 4 Loading system

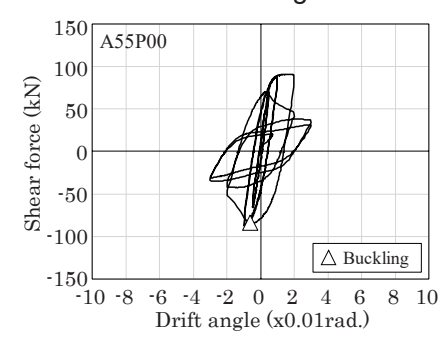

(a)No.6 A55P00

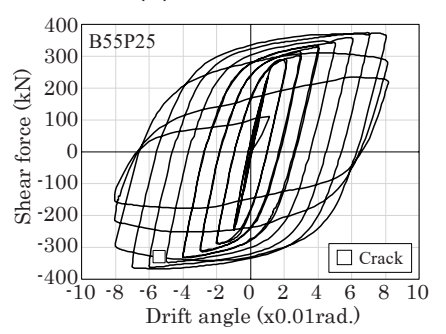

(e)No.19 B55P25

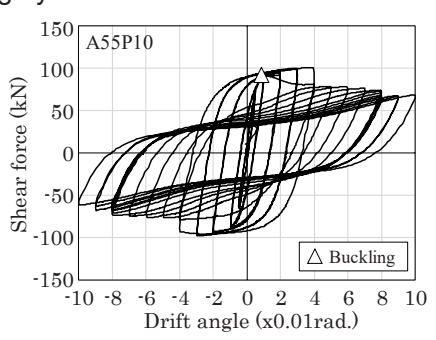

(b)No.8 A55P10

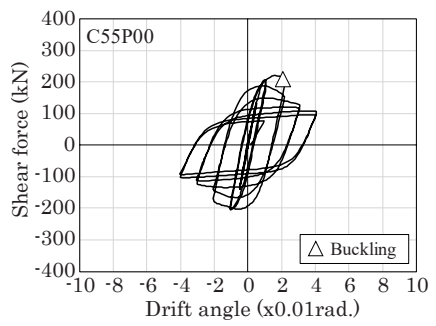

(f)No.20 C55P00

下パネル接合部の平行を維持し， $500 \mathrm{kN}$ ジャッキを用いて，せん断 変形角制御による静的正負交番繰り返し漸増載荷実験を行った。な お, 本研究では, せん断変形角 $\gamma$ は, 上下接合部間の相対水平変位 反を試験体パネル部高さで除した值と定義している.

実験に用いた載荷プログラムは，Fig. 3 に示すように， (1)～(3)の 3 通りである. 載荷プログラム(1) 漸増載荷を行うものであり, 載 荷プログラム(2) は, 載荷プログラム (1)で終局に至る変形レベルより 小さいレベルでの変形を多数回与えるものである. 載荷プログラム (3)は, 載荷当初から大きな変形を与えるものである. シリーズ $\mathrm{A} \sim \mathrm{C}$ の試験体はいずれも載荷プログラム(1)に従い, シリーズ D の 3 体の 試験体はそれぞれ載荷プログラム (1)〜 (3)に従って実験を実施した.

\section{3 履歴特性}

Fig. 5 に, 代表的な試験体 8 体 (No. 6, No. 8, No. 9, No. 11, No. 19 ， No. 20， No. 22，No. 24）の荷重 Q - せん断変形角 $\gamma$ 関 係を示す. 図中の $\square$ 印と $\triangle$ 印は試験体が終局状態に達したと判断し た点を示しており,鋼板パネルに亀裂が発生したと判断した時点 $(\square$ 印)，あるいは，パネルに顕著な局部座屈が発生した時点（ $\triangle$ 印）を 示す. 終局状態の判定基準の詳細は, 後述の 2.5 節を参照されたい.

実験結果より，パネルを拘束する PP 板厚が大きいほど最大耐力 時のせん断変形角, および座屈発生時のせん断変形角が大きくなる 傾向が見られた（Fig. 5(a h)）．シリーズ A において，無拘束の試 験体 A55P00 (Fig. 5(a)) と PP 板厚 10 mm の試験体 A55P10 (Fig. 5(b)) は，それぞれ-0.02rad.(1)(0.02rad.のサイクル 1 回目の負側) と +0.04rad.(2)のサイクルでパネルの座屈により終局状態に達した. 一 方で $\mathrm{PP}$ 板厚 $15 \mathrm{~mm}$ の試験体 A55P15 (Fig. 5 (c)) と PP 板厚 $25 \mathrm{~mm}$ の試験体 A55P25（Fig. 5(d)）は，共に+0.07rad.のサイクルでパネ ルの隅部に亀裂が生じることにより終局状態に達するまで, ほぼ同 じ履歴ループを描いた。このことから, 無拘束あるいは PP 板厚が 不十分な場合, 試験体は座屈により終局状態を迎え, その恋形性能 は PP 板厚が大きいほど向上寸ることが分かる. 一方で, PP 板厚が 十分な場合は, 試験体は亀裂により終局状態を迎え, PP 板厚による 変形性能の差はほとんどない。 また, パネルのサイズがシリーズ $\mathrm{A}$

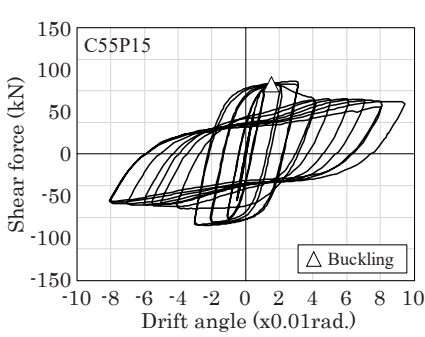

(c)No.9 A55P15

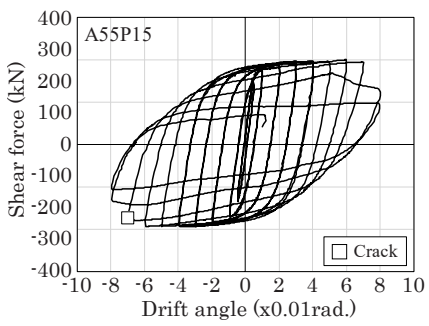

(g)No.22 C55P15

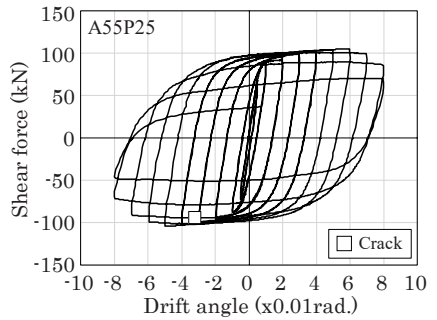

(d)No.11 A55P25

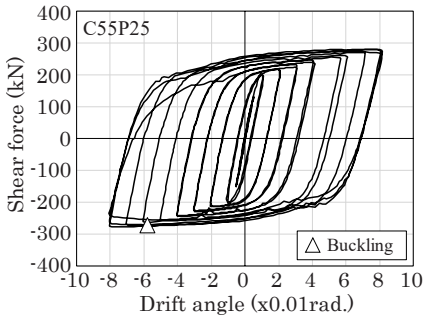

(h)No.24 C55P25

Fig. 5 Measured shear force - drift angle relationships 
よりも大きいシリーズ B の PP 板厚 $25 \mathrm{~mm}$ の試験体 B55P25 (Fig. 5(e)）も，0.08rad.の 1 回目のサイクルで亀裂により終局に達するま で安定した紡錘型の履歴ループを示しており, PP 板厚が十分であ れば，パネルサイズによらず高い変形性能を示すことが分かる。低 降伏点鋼を用いたシリーズ C においては, 無拘束の試験体 C55P00

(Fig. 5 (f)), PP 板厚 $15 \mathrm{~mm}$ の試験体 C55P15（Fig. 5(g)), PP 板 厚 25mm の試験体 C55P25（Fig. 5(h)）は，それぞれ+0.02rad.(2), $+0.04 \mathrm{rad}$. (1)，-0.08rad.(2)のサイクルで座屈により終局状態に達し た. PP 板厚 $25 \mathrm{~mm}$ で普通鋼を用いた試験体 B55P25 が亀裂により 終局状態に達したのに対して, 同じ PP 板厚で低降伏点鋼を用いた 試験体 C55P25 は亀裂が生じず, 座屈により終局に達した.これは, 低降伏点鋼の方が破断伸びが大きく, 亀裂が生じにくいためと考え られる。両試験体は共に 0.08rad. のサイクルまで安定した履歴ル 一プを示しており, せん断パネルに普通鋼を用いた場合も, 低降伏 点鋼を用いた場合と同じく, 試験体は高いエネルギー吸収性能を有 することが分かる．またシリーズ A では幅厚比 $(b / t) 55$ の場合, 座 屈を防ぐために必要な PP 板厚は $15 \mathrm{~mm}$ であったが, シリーズ $\mathrm{C}$ で は, より大きい PP 板厚を必要としており, パネルサイズ, 鋼材種 別によって必要な PP 板厚が異なることが窺える.

Fig. 6 に, 載荷プログラムの異なる試験体 3 体（No.29, No.30, No.31）の荷重 - せん断変形角関係を示す.いずれも座屈により終局 状態に達したと判断した。試験体 D55P20C1 は，0.06rad.まで紡鍾 型の履歴ループを描いた。試験体 D55P20C2 は，0.02rad.サイクル を 40 回，0.04rad.サイクルを 6 回経験後も終局状態に到達せず，そ の後, 0.08rad.の正側の半サイクルで終局となった。なお, 載荷中の パネルの温度上昇は確認されなかった。試験体 D55P20C3 では, $0.1 \mathrm{rad}$.サイクルを 1 度を経験した後，負側領域で急激な耐力低下が みられた。これらより, 載荷プログラムによって, 終局時の変形量が 異なることが分かる.

\section{4 エネルギー吸収性能}

シリーズ $\mathrm{C}$ の各試験体のエネルギー吸収率 $e$ - 累積塑性変形角関
係を鋼板厚さごとに比較したものを Fig. 7(a, b)に，シリーズ A C の $\mathrm{PP}$ 板厚 $15 \mathrm{~mm}, 25 \mathrm{~mm}$ の試験体を $\mathrm{PP}$ 板厚ごとに比較したもの を Fig. 7(c,d)に示す.ここで, エネルギー吸収率 $e$ は, 次式により 計算される無次元量であり, 試験体サイズや鋼材の降伏点によらず, エネルギー吸収量を比較するために定義した指標である.

$$
e=E /\left(V \cdot \sigma_{y}\right)
$$

ここに, $E$ : パネルの総エネルギー吸収量 $\left(=\int Q d \delta\right)[\mathrm{Nmm}], V:$ パ ネル部の体積 $(=t b h)\left[\mathrm{mm}^{3}\right], \sigma_{y}$ : 降伏点 $\left[\mathrm{N} / \mathrm{mm}^{2}\right]$. なお，正負方向 別の累積塑性変形角 19) とエネルギー吸収率を求めており, $\mathrm{x}$ 軸の負 值は，負側変形時の累積塑性変形角を示寸.

図中の $\square$ 印は終局状態に達した点を示すが, Fig. 7(a, b)を見ると， 終局状態に達すると累積塑性変形角に対するエネルギー吸収率の勾 配が低下し, エネルギー吸収性能が低下寸ることが分かる.一方で, 終局状態に達するまでは PP 板厚によらず，ほぼ等しいエネルギー 吸収性能を示している。試験体の PP 板厚が大きいほど，より大き な累積塑性変形角まで高いエネルギー吸収性能を維持することが分 かる.また Fig. 7(c,d)より, 終局状態に至り, エネルギー吸収性能 が低下し始める累積塑性変形角は, PP 板厚が同じ場合, パネルサイ ズが小さく, 幅厚比が小さいほど，大きくなる傾向が見られた。ま た, 試験体 B55P20 と C55P20 を比較すると, パネルは同サイズで あるが，終局時の累積塑性変形角が大きく異なった，これは，低降 伏点鋼は，降伏点が普通鋼より小さいことにより，後述の一般化幅 厚比が小さくなり，座屈の発生が遅れ，より大変形時までエネルギ 一吸収性能を維持できたためと考えられる.また, Fig. 7(c,d)より, パネルのサイズや鋼材種別によらず，終局状態に達するまでのエネ ルギー吸収率の勾配はほぼ等しいことが分かる。

Fig. 8 に試験体 D55P20C1，D55P20C2，D55P20C3（シリーズ D) のエネルギー吸収率 $e$ - 累積塑性変形角関係を示す.シリーズ $\mathrm{D}$ の試験体についても，その他の試験体と同様，終局状態に達寸るま ではエネルギー吸収率はほぼ一定の勾配を維持しており, 終局状態 に達すると吸収性能は低下寸ることが確認された。しかしながら， 終局時の累積塑性変形角は，載荷履歴によって異なっており，終局

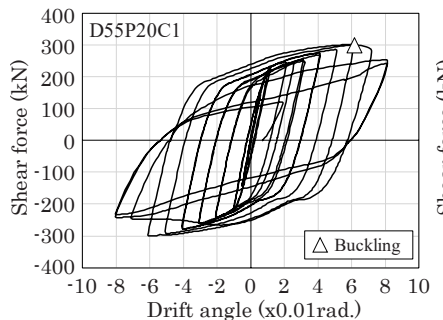

(a)No.29 D55P20C1

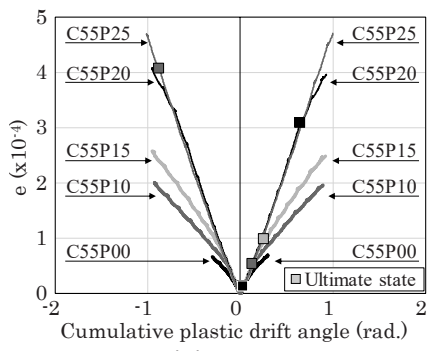

(a)PL6.0LY

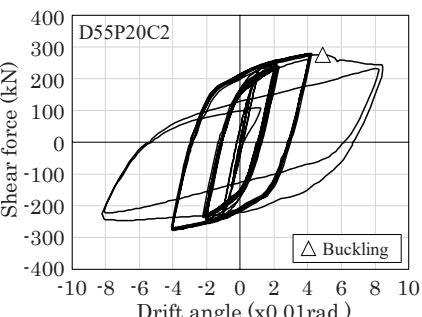

(b)No.30 D55P20C2

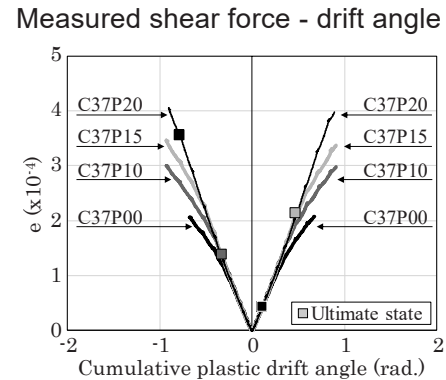

(b)PL9.0LY

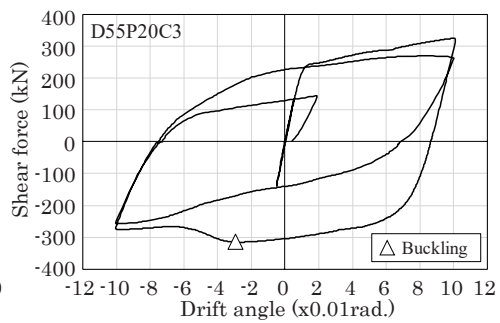

(c)No.31 D55P20C3

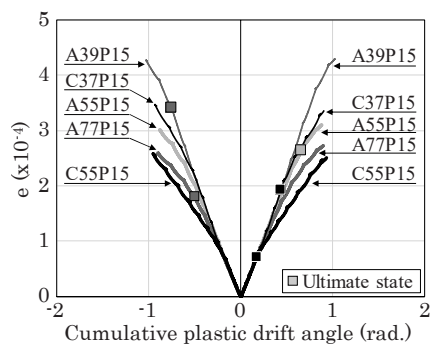

(c) $t_{c}=15 \mathrm{~mm}$

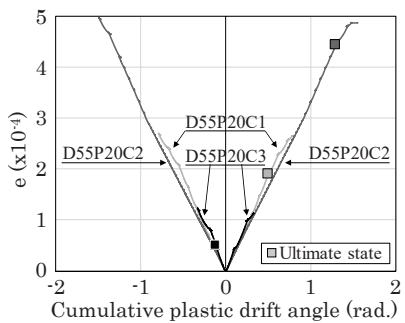

Fig. 8 Relationship between $e$ and $\gamma_{u}$ of series $D$

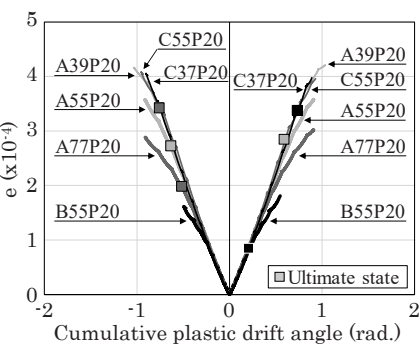

(d) $t_{c}=20 \mathrm{~mm}$

Fig. 7 Relationships between energy-absorption ratio $(e)$ and cumulative plastic drift angle $\left(\gamma_{u}\right)$ 
状態に達するまでのエネルギー吸収量は, 載荷履歴の影響を受ける ことが分かる。

\section{5 終局状態}

鋼構造制振設計指針 19)において, 繰り返し載荷下における, せん 断パネルの主な終局状態の判定基準は以下の 3 種類と定められてい る.

\section{(1)破断または大きな亀裂が発生した時点}

(2)最大耐力の 9 割まで耐力低下した時点

(3)顕著な局部座屈が生じ, 局所的に耐力低下し, 荷重一変形角関 係に負勾配が生じた時点

本研究の試験体の終局状況 10) 14) は，パネルの四隅に亀裂が生じ たものと局部座屈を生じたものとに大きく大別できる. そこで本研 究では, 終局状態の判定基準を以下のように設定した.

「亀裂」: 試験後にパネルの四隅に亀裂が生じたもの. 最大耐力の
9 割まで耐力が低下した時点を終局状態と判断する.

「座屈」: 顕著な局部座屈が生じたもの. 荷重変形角関係の接線勾 配が負勾配となった時点を終局状態と判断する.

本研究における具体的な判定手順として, まず実験終了後の試験 体において，主に亀裂の有無により終局となった要因を判定し，そ の後, 水平力変形角関係から終局状態に至った点を抽出した. Fig.9 に試験体の終局状態の例を示す．無拘束の試験体ならびに拘束板の 厚さが不十分であった試験体は，Fig. 9(a,b)のように，面外変形が 卓越し, 座屈により耐力低下する. 一方で, 十分な拘束板厚を持つ 試験体は，拘束板により試験体の面外変形ならびに座屈による耐力 低下を防ぎ，Fig. 9(c)のように鋼板に亀裂が入ることで而力低下す る. 各試験体の終局状態の判定結果および終局時の累積塑性変形量 をTable 3 に示す。普通鋼を用いたシリーズ A, B, D の試験体にお いて，2.3 節で述べたように，PP 板厚が不十分であった試験体は終 局状態が座屈と判断され，PP 板厚が十分であった試験体は亀裂と

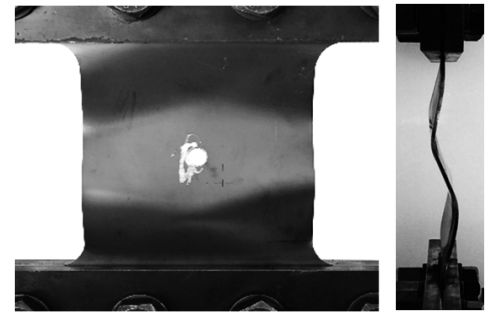

(a) Buckling (A55P00)

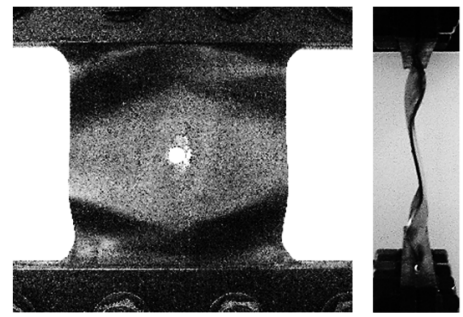

(b) Buckling (A55P10)

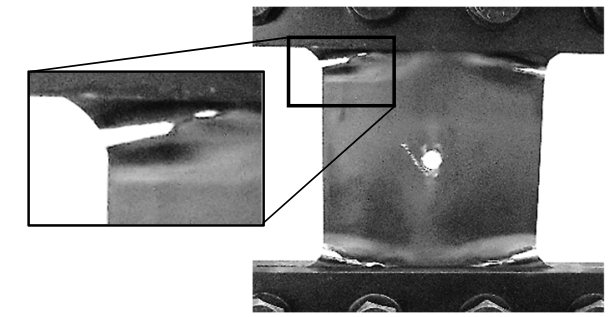

(c) $\operatorname{Crack}(\mathrm{A} 55 \mathrm{P} 25)$

Fig. 9 Ultimate state of specimens

Table 3 Strength and deformation at ultimate states

\begin{tabular}{|c|c|c|c|c|c|c|c|c|c|c|c|c|c|c|c|c|c|}
\hline \multirow{2}{*}{ Series } & \multirow[t]{2}{*}{ No } & \multirow[t]{2}{*}{ Specimen } & \multirow[t]{2}{*}{ Steel } & $t_{c}$ & \multirow{2}{*}{$\begin{array}{c}\text { Ultimate } \\
\text { state }\end{array}$} & $\exp \gamma_{u}$ & ${ }_{e x} Q_{\max }$ & ${ }_{c a l} Q_{b u 1}$ & ${ }_{c a l} Q_{b u 2}$ & ${ }_{c a l} Q_{c r 1}$ & ${ }_{c a l} Q_{c r 2}$ & $\left(d / t_{w}\right)_{B E}$ & ${ }_{c a l} Q_{y}$ & $c a l K_{i}$ & $\gamma_{y}$ & $\bar{\gamma}_{B}$ & $\bar{\gamma}_{B} / \gamma_{y}$ \\
\hline & & & & $\mathrm{mm}$ & & rad. & $\mathrm{kN}$ & $\mathrm{kN}$ & $\mathrm{kN}$ & $\mathrm{kN}$ & $\mathrm{kN}$ & - & $\mathrm{kN}$ & kN/rad. & rad. & rad. & - \\
\hline \multirow{15}{*}{$\mathrm{A}$} & 1 & A77P00 & \multirow{5}{*}{$\begin{array}{l}\text { SS400 } \\
\text { PL2.3 }\end{array}$} & - & Buckling & 0.009 & 57 & \multirow{5}{*}{76} & \multirow{5}{*}{84} & 20 & 60 & 3.904 & \multirow{5}{*}{51} & \multirow{5}{*}{18,643} & \multirow{5}{*}{0.00272} & 0.007 & 2.7 \\
\hline & 2 & A77P10 & & 10 & Buckling & 0.114 & 69 & & & 35 & 60 & 3.691 & & & & 0.041 & 14.9 \\
\hline & 3 & $\mathrm{~A} 77 \mathrm{P} 15$ & & 15 & Crack & 0.500 & 71 & & & 54 & 66 & 2.577 & & & & - & - \\
\hline & 4 & A77P20 & & 20 & Crack & 0.508 & 72 & & & 78 & 95 & 0.555 & & & & - & - \\
\hline & 5 & A77P25 & & 25 & Crack & 0.559 & 72 & & & 105 & 118 & 0.229 & & & & - & - \\
\hline & 6 & A55P00 & \multirow{5}{*}{$\begin{array}{l}\text { SS400 } \\
\text { PL3.2 }\end{array}$} & - & Buckling & 0.039 & 91 & \multirow{5}{*}{101} & \multirow{5}{*}{112} & 53 & 86 & 2.793 & \multirow{5}{*}{68} & \multirow{5}{*}{25,735} & \multirow{5}{*}{0.00263} & 0.020 & 7.5 \\
\hline & 8 & $\mathrm{~A} 55 \mathrm{P} 10$ & & 10 & Buckling & 0.239 & 100 & & & 70 & 98 & 1.665 & & & & 0.043 & 16.2 \\
\hline & 9 & $\mathrm{~A} 55 \mathrm{P} 15$ & & 15 & Crack & 0.656 & 100 & & & 97 & 119 & 0.737 & & & & 年 & - \\
\hline & 10 & A55P20 & & 20 & Crack & 0.631 & 103 & & & 133 & 149 & 0.287 & & & & - & - \\
\hline & 11 & $\mathrm{~A} 55 \mathrm{P} 25$ & & 25 & Crack & 0.616 & 105 & & & 174 & 187 & 0.111 & & & & - & - \\
\hline & 12 & A39P00 & \multirow{5}{*}{$\begin{array}{l}\text { SS400 } \\
\text { PL4.5 }\end{array}$} & - & Buckling & 0.108 & 110 & \multirow{5}{*}{114} & \multirow{5}{*}{126} & 147 & 108 & 1.987 & \multirow{5}{*}{76} & \multirow{5}{*}{36,003} & \multirow{5}{*}{0.00212} & 0.039 & 18.3 \\
\hline & 13 & A39P05 & & 5 & Buckling & 0.189 & 114 & & & 149 & 112 & 1.755 & & & & 0.051 & 24.2 \\
\hline & 14 & A39P10 & & 10 & Buckling & 0.491 & 126 & & & 165 & 132 & 0.860 & & & & 0.065 & 30.9 \\
\hline & 15 & A39P15 & & 15 & Crack & 0.751 & 132 & & & 200 & 174 & 0.277 & & & & - & - \\
\hline & 16 & A39P20 & & 20 & Crack & 0.752 & 132 & & & 250 & 229 & 0.087 & & & & - & - \\
\hline B & 18 & B55P20 & $\begin{array}{l}\text { SN } 400 \\
\text { PI } 60-1\end{array}$ & 20 & Buckling & 0.210 & 326 & 336 & 370 & 270 & 337 & 1.471 & 224 & 95,470 & 0.00235 & 0.062 & 26.5 \\
\hline & 19 & B55P25 & PL6.0-1 & 25 & Crack & 0.588 & 374 & & & 320 & 379 & 0.909 & & & & & - \\
\hline & 20 & C55P00 & & - & Buckling & 0.029 & 220 & & & 213 & 219 & 2.256 & & & & 0.020 & 11.9 \\
\hline & 21 & C55P10 & & 10 & Buckling & 0.082 & 227 & & & 226 & 227 & 1.938 & & & & 0.035 & 21.2 \\
\hline & 22 & C55P15 & $\begin{array}{l}\text { LY225 } \\
\text { PL6 0LY }\end{array}$ & 15 & Buckling & 0.173 & 231 & 241 & 266 & 239 & 244 & 1.440 & 161 & 96,583 & 0.00166 & 0.038 & 22.6 \\
\hline & 23 & C55P20 & & 20 & Buckling & 0.601 & 274 & & & 271 & 273 & 0.893 & & & & 0.092 & 55.0 \\
\hline $\mathrm{C}$ & 24 & $\mathrm{C} 55 \mathrm{P} 25$ & & 25 & Buckling & 0.852 & 280 & & & 322 & 326 & 0.430 & & & & 0.127 & 76.3 \\
\hline & 25 & C37P00 & & & Buckling & 0.110 & 343 & & & 731 & 347 & 1.497 & & & & 0.049 & 30.5 \\
\hline & 26 & C37P10 & LY225 & 10 & Buckling & 0.304 & 350 & 345 & 380 & 739 & 365 & 1.222 & & & & 0.063 & 39.2 \\
\hline & 27 & C37P15 & PL9.0LY & 15 & Buckling & 0.437 & 375 & 345 & 380 & 757 & 400 & 0.832 & 230 & 143,854 & 0.0016 & 0.094 & 58.7 \\
\hline & 28 & C37P20 & & 20 & Buckling & 0.742 & 396 & & & 791 & 465 & 0.444 & & & & 0.108 & 67.4 \\
\hline & 29 & D55P20C1 & & & Buckling & 0.496 & 301 & & & & & & & & & 0.108 & 50.4 \\
\hline D & 30 & D55P20C2 & SN400 & 20 & Buckling & 1.291 & 280 & 300 & 330 & 281 & 323 & 1.144 & 200 & 92,907 & 0.00215 & 0.068 & 31.6 \\
\hline & 31 & D55P20C3 & PL6.U.Z & & Buckling & 0.116 & 326 & & & & & & & & & 0.101 & 46.7 \\
\hline
\end{tabular}

Note. $t_{c}$ : Thickness of confinement, ${ }_{e x} Q_{\max }$ : Maximum strength of specimen, exp $\gamma_{u}$ : Cumulative plastic drift angle at ultimate state of specimen, cal $Q_{b u 1}$ : Ultimate flexural strength calculated by Eq.(2), cal $Q_{b u 2}:$ Modified ultimate flexural strength calculated by Eq.(3), $c a l Q_{c r 1}$ : Buckling load calculated by Eq.(5), ${ }_{c a l} Q_{c r 2}$ : Modified buckling load calculated by Eq.(9), $\left(d / t_{W}\right)_{B E}$ : Equivalent reduced width-to-thickness calculated by Eq.(14), cal $Q_{y}$ : Yield bending strength calculated by Eq.(18), cal $K_{i}$ : Initial stiffness calculated by Eq.(19), $\gamma_{y}:$ Yield drift angle calculated by Eq.(17), $\bar{\gamma}_{B}:$ Equivalent shear buckling drift angle at ultimate state of specimen. 
判断される傾向がみられた. 次に, 同じ鋼板サイズと PP 板厚を持 つ試験体 B55P25 (No.19) と試験体 C55P25（No.24）を比較すると, それぞれの終局状態は亀裂と座屈と判定され, 異なる結果になった。 これは, それぞれに使用した鋼材が普通鋼か低降伏点鋼かの違いに よるものであり, 鋼材の降伏点や破断伸び等の性質によって必要な $\mathrm{PP}$ 板厚が異なることが推察される.

\section{3. 耐力評価}

本節では, 本試験体の耐力評価方法について述べる. 本試験体は, PP 板厚が十分であれば, 試験体の終局状態は亀裂となり, 曲げ耐力 を発揮し, PP 板厚が不十分であった場合は, 終局状態が座屈とな り, 試験体の耐力は座屈荷重により決定すると考える，尚，本試験 体の耐力評価においては漸増載荷を受ける場合を想定し, シリーズ $\mathrm{A} ， \mathrm{~B} ， \mathrm{C}$ の試験体に対して検討を行う。

\section{1 最大曲げ耐力}

本試験体のパネル部は，逆対称曲げを受ける状況下にあり，アス ペクト比 1.0 の試験体においては, パネルの上下端部が曲げ耐力に 達することで最大耐力を発揮する ${ }^{10)}$. そこで, パネルの上下端部の 断面が全塑性モーメント時の応力分布となると想定し, パネルの最 大曲げ耐力を式(2)により算定した.

$$
{ }_{c a l} Q_{b u 1}=\left(\frac{b^{2} t}{4} / \frac{h}{2}\right) \sigma_{y}=\frac{b^{2} t}{2 h} \sigma_{y}
$$

ここに, $b$ : パネルの幅, $t$ : パネルの厚さ, $h$ : パネルの高さ, $\sigma_{y}$ : パネルの降伏点.

各パネルサイズおよび鋼材種別で PP 板が最も厚いものは, 最大 曲げ耐力を発揮していると考え, それらの試験体 6 体の実験最大耐 力值と式(2)による最大曲げ耐力の計算值の比較を Fig. 10(a)に示す. 式(2)により求めた計算最大曲げ耐力は実験值を約 $10 \%$ 程度過小評 価することが分かった。これは, 応力集中緩和のためパネルの隅部 に設けたフィレット部の影響や鋼材のひずみ硬化の影響と考えられ る. せん断パネルの耐力を評価する上では, 最大曲げ耐力の過小評 価は安全側となるが, 実用化のためには PP 板厚の設計法が必要で あり，それには最大曲げ耐力を精度良く評価する必要があると考え られる。例として, パネルに座屈が生じないように PP 板厚を設計 する場合, パネルの最大耐力を後述の座屈荷重が上回るように PP 板厚を決定する方法が考えられるが，その際に最大耐力を過小評価 する式を用いてパネルの最大耐力を評価すると, 必要 PP 板厚を小
さく見積もり，実際には座屈が先行する恐れがある，そこで，本研 究では, PP 板厚を設計する際に用いる計算曲げ耐力においては, 鋼 材のひずみ硬化の影響等を簡潔に考慮し，降伏点を 1 割増した式(3) を用いるものとする。

$$
{ }_{c a l} Q_{b u 2}=\frac{b^{2} t}{2 h} \times 1.1 \sigma_{y}
$$

実験結果との対応を示したグラフを Fig. 10(b)に示す. Fig. 10 (b) より, 式(3)により求めた計算最大曲げ耐力は実験最大耐力を精度よ く評価していることが確認できる.

\section{2 座屈荷重評価式}

伊藤ら ${ }^{18}$ はスリット入り鋼板は, せん断力を受けると, 拘束材で 挟まれている鋼板部分が弱軸方向（面外方向）にねじれを伴って横 座屈をするとみなし, 座屈耐力算定式を提案している。本研究にお いても同様に，本試験体における鋼製パネルの座屈現象は横座屈に よるものと考える. 片持ち梁の横座屈荷重設計式 20)を適用すると, 無拘束せん断パネルの座屈荷重算定式は下式のようになる.

$$
Q_{c r 1}=4.013 \frac{\sqrt{G_{s} J_{s} E_{s} I_{s}}}{(h / 2)^{2}}
$$

ここに, $G_{s} J_{s}$ : パネルの据り剛性， $E_{s} I_{s}$ : パネルの面外曲げ剛性

更に，PP 板で拘束されたパネルにおいては，PP 板が曲げ剛性の 増加にのみ寄与寸ると仮定することで, 拘束せん断パネルの座屈荷 重の算定式が式(5)のように得られる.

$$
{ }_{\text {cal }} Q_{c r 1}=4.013 \frac{\sqrt{G_{s} J_{s}\left(E_{s} I_{s}+n E_{c} I_{c}\right)}}{(h / 2)^{2}}
$$

ここに, $n: \mathrm{PP}$ 板枚数, $E_{c} I_{c}: \mathrm{PP}$ 板の面外曲げ剛性.

しかし，本実験結果と式(5)から求めた座屈荷重を比較すると， Table 3 に示寸通り, 本試験体の座屈荷重は PP 板の有無に依らず 実験值と計算值が大きく異なる。これは，本試験体は鋼材が塑性化 した後に終局状態に達しているが，式(5)では鋼材の塑性化の影響を 考慮していないことが原因と考えられる.

そこで，一般化幅厚比を用いて式(5)を修正し，新たな座屈荷重設 計式を提案する，まず，無拘束の試験体の座屈荷重に着目し，修正 係数を求める. 縦軸を式(4)による計算座屈荷重 $c a l Q_{c r 1}$ と実験最大耐 力 ${ }_{e x} Q_{\max }$ の比 $\alpha$ とし, 横軸を式(6)による一般化幅厚比 $\xi$ とて無 拘束の試験体の実験結果をプロットした Fig. 11 を見ると，実験結 果はほぼ同一線上にプロットされ，高い関係性が見られた。

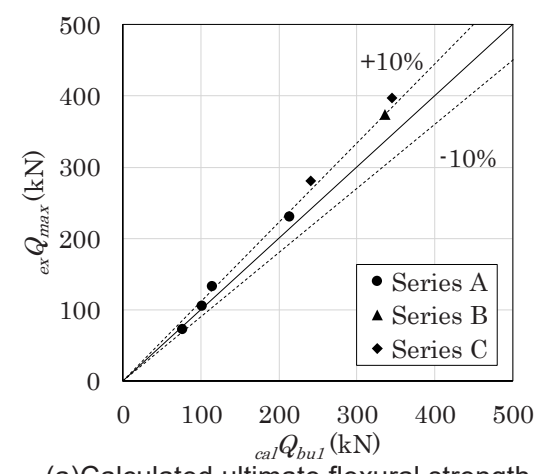

(a)Calculated ultimate flexural strength

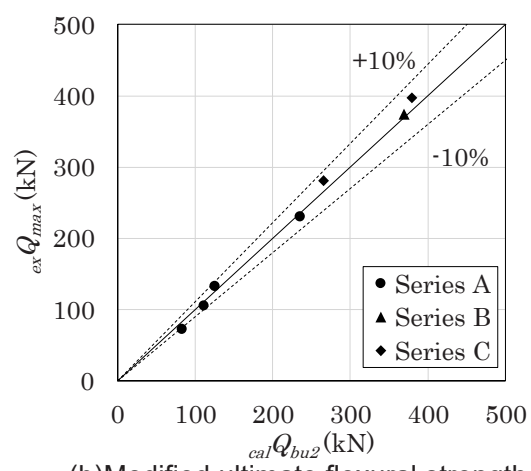

(b)Modified ultimate flexural strength

Fig. 10 Comparison of experimental and calculated ultimate flexural strengths

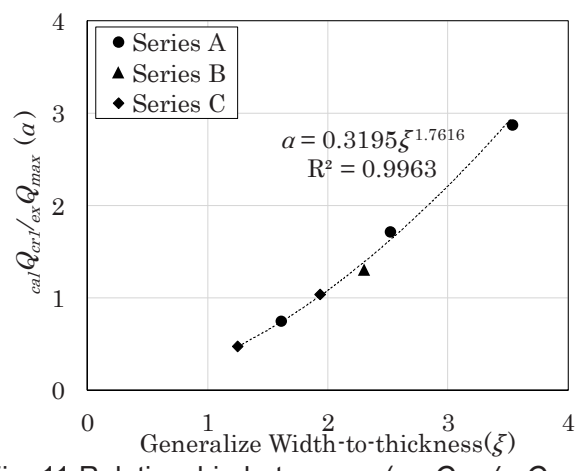

Fig. 11 Relationship between $\alpha\left(=_{c a l} Q_{c r 1} /\right.$ ex $\left._{\max }\right)$ and $\xi$ (= generalized width-to-thickness) 


$$
\xi=\frac{b}{t} \sqrt{\frac{\sigma_{y}}{E_{s}}}
$$

そこで, Fig. 11 の近似曲線として得られる式を, 式(7)の修正係 数 $\alpha$ として用い, 無拘束試験体の座屈荷重算定式を式(8)のように修 正する. ただし, この関係式は, せん断パネルのアスペクト比によ って変化するものと考えられる.

$$
\begin{gathered}
\alpha=0.32 \xi^{1.76} \\
Q_{c r 2}=4.013 \frac{\sqrt{G_{s} J_{s} E_{s} I_{s}}}{(h / 2)^{2}} \times \alpha
\end{gathered}
$$

PP 板で拘束された試験体に対しては, 式(9)により, 座屈荷重を 算定する.

$$
{ }_{c a l} Q_{c r 2}=4.013 \frac{\sqrt{G_{s} J_{s}\left(\alpha^{2} E_{s} I_{s}+n E_{c} I_{c}\right)}}{(h / 2)^{2}}
$$

ここで, 本研究で提案された修正係数 $\alpha$ の適用範囲はパネルの一 般化幅厚比 1.25 から 3.57 までとし, 式(9)はアスペクト比 1 のパネ ルに対して適用可能とする. 実験最大耐力と計算最大曲げ耐力の比 と, 座屈荷重計算值と計算最大曲げ耐力の比の関係において, 修正 係数を用いない場合（式(5)を使用）と用いた場合（式(9)を使用）の 評価を Fig. 12 に示す。なお最大曲げ耐力の計算には式(3)を使用し た。図の縦軸は実験最大耐力を計算曲げ耐力で除した值であり, 横 軸は計算座屈荷重を計算曲げ耐力で除した值である。図の原点から 引かれた斜線は, 実験最大耐力が計算座屈荷重と一致することを示 し，斜線の上方に点が位置する場合，その試験体の計算座屈荷重は 実験結果を過小評価したことを示す。図中に水平に引いた線は, 実 験最大耐力が計算曲げ耐力と一致することを示し, 水平線の上方に 点が位置する場合は計算曲げ耐力が実験結果を過小評価することを 意味している. 図中の実線に点が近いほど, 計算式の精度が高いこ

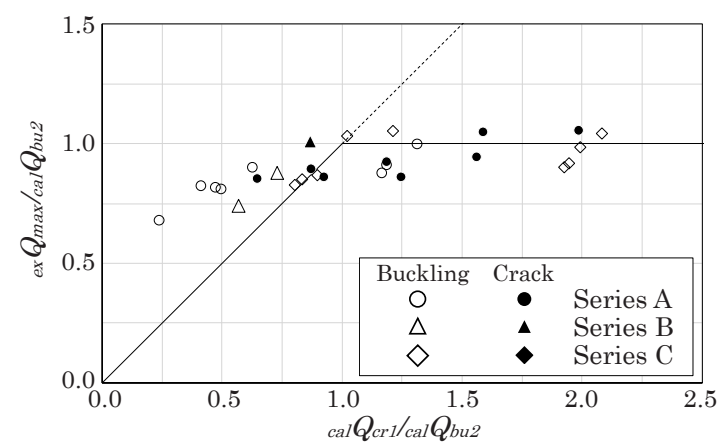

(a) Evaluation without $\alpha$

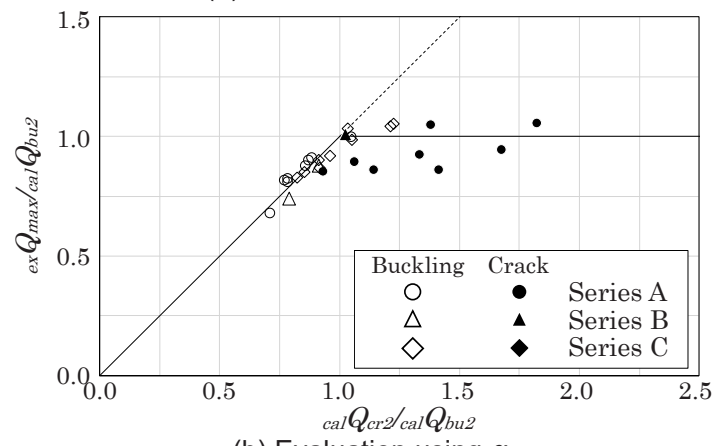

(b) Evaluation using $\alpha$

Fig. 12 Evaluation of maximum strength
とを示す. 図より, 本研究の修正係数を用いた提案式（式(9)）は, $\mathrm{PP}$ 板で拘束された試験体の座屈荷重を精度よく評価していること が分かり，座屈により終局に達した試験体において，耐力比 $e_{x} Q_{\text {max }}$ $I_{c a l} Q_{c r 2}$ は $0.85 \sim 1.15$ の範囲にあり, 平均は 0.98 であった。 また, 本提案式は, 本実験変数内においては, 鋼板パネルのサイズによら ず座屈荷重を精度よく評価できている，本提案式を用いて計算され る最大曲代耐力と座屈荷重の一覧を Table 3 に示す.

鋼製パネルの補剛材である PP 板の厚さによって座屈荷重は変化 寸る，そのため，パネルの座屈を防ぐために必要となる PP 板厚は 下記の式(10)を満足する必要がある.

$$
{ }_{c a l} Q_{b u 2}<{ }_{c a l} Q_{c r 2}
$$

この式を展開し, 必要な PP 板厚 ${ }_{r} t_{c}$ は次式により得られる.

$$
\frac{{ }_{r} t_{c}}{t}>\sqrt[3]{0.11 \frac{E}{n E_{c}}\left(\frac{h}{b}\right)^{2} \xi^{4}-0.1 \xi^{3.52}}
$$

上式を用いることで，アスペクト比 1 の鋼板の座屈を防ぐために必 要な PP 板厚を推定寸ることが可能と考えられる.

\section{4. 変形性能に関する評価指標の計算式の提案}

せん断パネルは，建物が終局に至るまで機能を維持できるように 設計する必要があり，そのためには，せん断パネルが終局状態に達 するまでの保有性能を規定する必要がある。鋼構造制振設計指針 19) においては，(1)累積塑性変形角（2)累積損傷度（3)等価せん断座屈 変形角という保有性能を評価する 3 種類の指標が挙げられており, この 3 種類の指標はいずれも繰り返し変形下におけるパネルの変形 能力の指標として利用されている．しかし，指針にて規定されてい るこれらの指標の評価式は，いずれも従来のフランジ付のせん断パ ネルに適用するように策定されたものである，そこで，本節では， 本試験体の変形性能に関して, これらの指標の評価式の構築を試み る。本論では，座屈により終局を迎える試験体を主対象として，(1) 累積塑性変形角と(3)等価せん断座屈変形角の 2 つの評価指標につ いて検討する.

\section{1 累積塑性変形角}

累積塑性変形角は，せん断パネルの繰り返し載荷時における保有 性能を評価する指標である，試験体が終局状態に達した時点を性能 保証限界とし, その時点での累積塑性変形角を評価する. 田中, 佐々 木ら 4,5 は, 座屈によって終局となるフランジ付のせん断パネルの保 有性能に関して, 性能保証限界時の累積塑性変形角と, 式(12)によ り得られる換算幅厚比 $\left(d / t_{w}\right)_{\mathrm{B}}$ とに関係性があることを示している. 田中らは，試験体が性能保証限界に至ったときの正負方向別の累積 塑性変形角のうち，いずれか小さい值 $\gamma_{u}$ と換算幅厚比 $\left(d / t_{w}\right)_{\mathrm{B}}$ との間 には式(13)が良好に成立することを示している4).

$$
\left(\frac{d}{t_{w}}\right)_{B}=\left(\frac{d}{t_{w}}\right) \cdot \sqrt{\frac{\sigma_{y}}{E}} \cdot \sqrt{\frac{\sigma_{u}}{\sigma_{y}}}=\left(\frac{d}{t_{w}}\right) \cdot \sqrt{\frac{\sigma_{u}}{E}}
$$

$1.16 \leqq\left(d / t_{W}\right)_{\mathrm{B}} \leqq 2.14$ のとき

$$
\gamma_{u}=2.936 \cdot\left\{\left(\frac{d}{t_{w}}\right)_{B}\right\}^{-3.569}
$$

ここに, $\left(d / t_{w}\right)$ : フランジ付のせん断パネル幅厚比, $E$ : ヤング係数, 
$\sigma_{y}$ : パネル鋼材の降伏点, $\sigma_{u}$ : 鋼材の引張強さ.

上記の考えを参考に, PP 板で補剛した本試験体の終局時累積塑 性変形角について換算幅厚比による評価を試みる. 換算幅厚比（式 (12))は，形状により定まる幅厚比を使用鋼材の降伏ひずみと降伏比 の逆数で補正したものであり, 補剛材の効果は含まれていない. フ ランジ付きせん断パネルにおいては，スチフナによる効果を評価す る場合, 補剛パネルの弾性せん断座屈の固有值解析から求めた座屈 応力と等しい座屈応力を持つスチフナなしパネルの幅厚比により算 定される換算幅厚比が用いられる ${ }^{19)}$ ，そこで，本論では，PP 板で 補剛された試験体の換算幅厚比に関して, 該当試験体の座屈荷重と 同等の座屈荷重を持つ無拘束パネルの換算幅厚比として求めること とし, 以下，この換算幅厚比を等価換算幅厚比と称する. 等価換算 幅厚比は, 式(8)より求まる座屈荷重が式(9)より求まる座屈荷重 ${ }_{c a l} Q_{c r 2}$ と等しい值となるときの換算幅厚比であり, その等式を右辺 が換算幅厚比となるように整理して得られる次式により計算される。

$$
\left(\frac{d}{t}\right)_{B E}=\left\{1.89 \cdot \beta^{2} \cdot \frac{c a l}{\sigma_{y} \cdot b t}\right\}^{-4.17} \cdot \sqrt{\frac{\sigma_{u}}{\sigma_{y}}}
$$

ここで ${ }_{c a l} Q_{c r 2}$ : 計算座屈荷重(式(9)), $\sigma_{y}$ : パネル鋼材の降伏点, $\sigma_{u}$ : 鋼材の引張強さ, $B:$ アスペクト比 $(=h / b)$

式(14)上り求めた換算幅厚比（以下，等価換算幅厚比 $\left.(d / t)_{\mathrm{BE}}\right)$ と 実験結果より得られた終局時累積塑性変形角の関係を Fig. 13(a)に 示す。ここでは，座屈によって終局に至った試験体のみを掲載して いる. Fig. 13(a)より，シリーズ D の試験体は，鋼材や PP 板は同等 のものであるため, 等価換算幅厚比は同じになるが, 試験体の保有 累積塑性変形角が載荷プログラムによって異なるため, 等価換算幅 厚比で評価することが出来ないことが分かる。一方で, せん断パネ ルの地震時の応答は, 比較的繰り返しの回数が少なく, せん断パネ ルの地震時の損傷は漸増振幅試験により把握できるとされている 18). そこで, Fig. 13(b)に示すように, 載荷プログラム (1)による漸増 載荷実験の結果であるシリーズ $\mathrm{A} ， \mathrm{~B} ， \mathrm{C}$ の試験体に対象を絞って 検討したところ，等価換算幅厚比と終局時累積塑性変形角に相関関 係が見られ, 等価換算幅厚比が小さいほど, 終局時累積塑性変形角 が大きくなる傾向が見られる. 等価換算幅厚比 $(d / t)_{\mathrm{BE}} \leqq 2.8$ の範囲 で, 近似曲線を作成したところ, 以下のような関係式(式(15))が得ら れた.

$$
\gamma_{u}=1.62 \cdot e^{-1.46\left(\frac{d}{t}\right)_{B E}}
$$

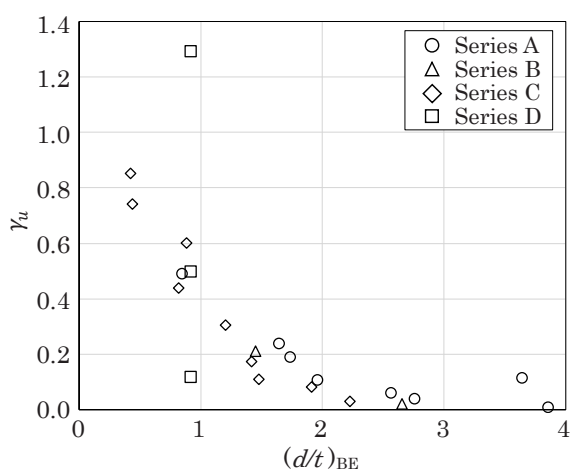

(a) Buckled specimen of all series

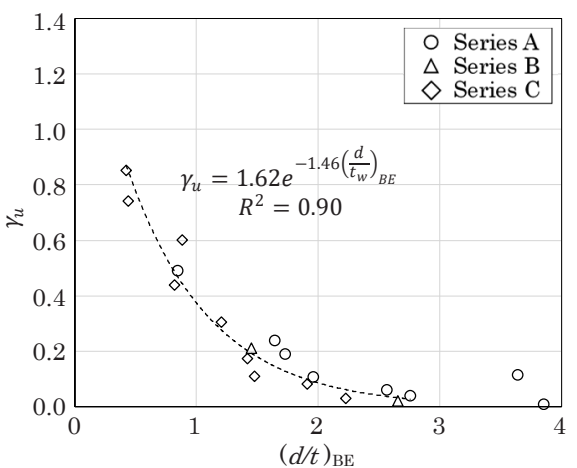

(b) Buckled specimen of Series A through C Fig. $13 V_{B}-(d / t)_{B E}$ relationships

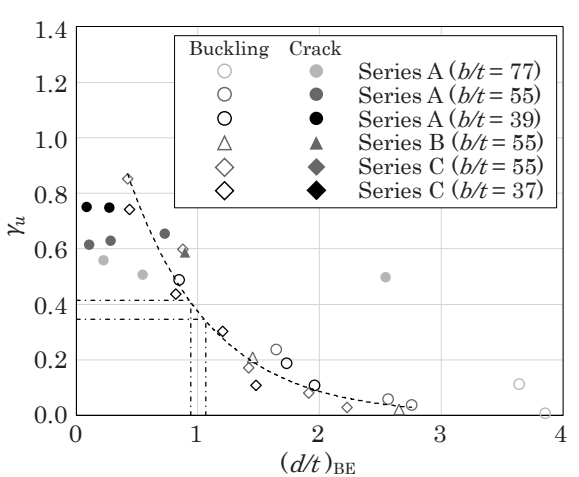

(c) All specimen of Series A through C 


\section{2 等価せん断座屈変形角}

等価せん断座屈変形角とは, 繰り返し載荷時におけるせん断力 0 の時点から最大変形までの変形角のことである ${ }^{19)}$. シアリンク形の せん断パネルダンパーに関して, Kasai ら 6,7) は, 繰り返し載荷の履 歴によらず, 最大の変形角振幅がせん断座屈発生の主因であること を示し, せん断座屈発生による耐力減少時点を予測しうる評価式を 提案している.このことから, せん断パネルにおいても, せん断座 屈変形角は使用限界の判定指標として利用できると考えられている 19). 繰返し載荷時のフランジ付きせん断パネルにおいては, 塑性座 屈が生じる等価な変形角 $\bar{\gamma}_{B}$ とパネルの降伏せん断変形角 $\gamma_{y}$ の比 $\bar{\gamma}_{B} / \gamma_{y}$ は, 基準化幅厚比により算出される ${ }^{8,9)}$.

しかしながら, 本試験体は, 既往のフランジ付きせん断パネルと 境界条件が異なるため, 既往の提案式を適用することはできない. そこで, 前項で求めた等価換算幅厚比(式(16))を用いて等価せん断座 屈変形角を評価することを検討した。

本試験体の $\bar{\gamma}_{B} / \gamma_{y}$ を評価することを試みる， $\bar{\gamma}_{B}$ は荷重 0 の点から の繰返し載荷中の最大值までの全振幅である. 本研究では, パネル の降伏せん断変形角 $\gamma_{y}$ は式(17)のように計算降伏曲代耐力を計算 初期剛性で除して得られる計算降伏せん断変形角 ${ }_{c a l} \gamma_{y}$ を用いること とした。 パネルの計算降伏曲げ耐力は式(18)により得られるものと し, 計算初期剛性は, パネル部の弾性曲げ変形量と弾性せん断変形 量を考慮し, 式(19)により求める. なお, パネル四隅のフィレット 部の影響を無視し，鋼板が平面形状を保持寸ると仮定している.

$$
\begin{gathered}
{ }_{c a l} \gamma_{y}=\frac{{ }_{c a l} Q_{y}}{c a l} K_{i} \\
{ }_{c a l} Q_{y}=\frac{b^{2} \cdot t_{w} \cdot \sigma_{y}}{3 h} \\
{ }_{c a l} K_{i}=\frac{1}{\frac{h^{3}}{E_{s} b^{3} t}+\frac{\kappa h}{G_{s} b t}}
\end{gathered}
$$

ここに, $c a l Q_{y}$ : 計算降伏曲げ耐力, ${ }^{2} a l K_{i}$ : 計算初期剛性, $b:$ パネル の幅, $t$ : パネル厚さ, $\sigma_{y}$ : 鋼材の降伏耐力, $h$ : パネル高さ, $E_{s}$ : 鋼材のヤング係数, $K$ : せん断断面積係数 $(=1.2), G_{s}$ : 鋼材のせん断 弾性係数

式(16), 式(17)より得られた, $\bar{\gamma}_{B} /{ }_{c a l} \gamma_{y}$ と等価換算幅厚比の関係を Fig. 14 に示し, 計算結果一覧を Table 3 に示す.なお，座屈により 終局状態に達したと判断された試験体の実験結果のみを対象として

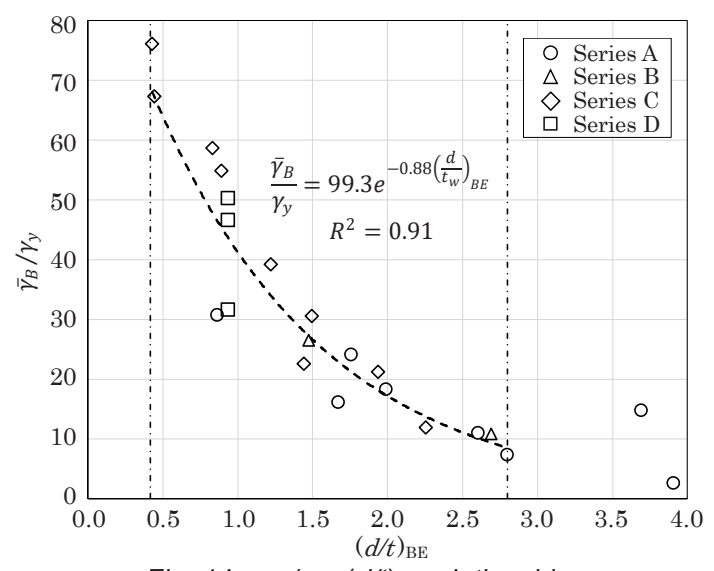

Fig. $14 y_{B} / \gamma_{y}-(d / t)_{B E}$ relationship
いる. Fig. 14 より, 実験結果はほぼ同一線上にプロットされており, 等価換算幅厚比と $\bar{\gamma}_{B} /{ }_{c a l} \gamma_{y}$ に関係性が見られ，等価換算幅厚比が小 さいほど, $\bar{\gamma}_{B} /{ }_{\text {cal }} \gamma_{y}$ は大きくなる. また載荷プログラムの異なるシリ 一ズ $\mathrm{D} の \bar{\gamma}_{B} /{ }_{\mathrm{cal}} \gamma_{y}$ につても比較的小さなバラつきで評価できてい ることが分かる.この実験結果の近似曲線として, 式(20)が得られ る. 適用範囲は $0.43 \leqq(d / t)_{\mathrm{BE}} \leqq 2.8$ とする.

$$
\frac{\bar{\gamma}_{B}}{{ }_{\text {cal }} \gamma_{y}}=99.3 \cdot e^{-0.88\left(\frac{d}{t}\right)_{B E}}
$$

この式を用いることで, 本提案パネルの等価せん断座屈変形角を評 価できると考えられる.

\section{5. 結論}

本論では, 本研究のせん断パネルの履歴性状を明らかにすること を目的として, 実験的検討を行った。また, せん断パネルの耐力評 価法ならびに変形性能評価法に関する検討を行った，得られた知見 を以下に記す。

1)十分な板厚を有する PP 板により拘束された鋼板パネルは, 漸増 載荷に対して変形角 $0.07 \mathrm{rad}$.まで高い耐力ならびに高いエネルギ 一吸収性能を発揮する。

2) 無拘束あるいは PP 板厚が不十分な場合, 試験体は座屈により終 局状態を迎え，PP 板厚が大きいほど変形性能が向上する．PP 板 厚が十分な場合は, 試験体は亀裂により終局状態を迎え, PP 板厚 による変形性能の差はほとんど生じない，鋼板の座屈を防ぐため に必要な PP 板厚は, パネルサイズ, 鋼材の性質によって異なる.

3) 終局状態に達すると累積塑性変形角に対するエネルギー吸収率の 勾配が低下し, エネルギー吸収性能が低下寸るが，終局状態に達 するまでは PP 板厚によらず，ほぼ等しいエネルギー吸収性能を 示す.

4) 終局時の累積塑性変形角は, 載荷履歴によって異なっており, 終 局状態に達するまでのエネルギー吸収量は, 載荷履歴の影響を受 ける.

5) 十分な PP 板厚で拘束された本提案パネルの最大耐力は, 全塑性 モーメント時の計算耐力により安全側に評価できる. 一方, 鋼材 のひずみ硬化の影響を考え，降伏点を 1 割増しすることで，本パ ネルの最大耐力を精度良く評価でき, 座屈耐力との比較により $\mathrm{PP}$ 板厚を決定する際においては，後者の計算により評価する.

6) 既往の横座屈荷重設計式に拘束材の曲げ剛性と一般化幅厚比によ る修正係数を加えた提案式を用いることで，拘束鋼板パネルの耐 力を精度良く評価できる．またこの座屈荷重の提案式と上記の最 大耐力評価式から, パネルの座屈を防ぐために必要となる PP 板 厚の推定式を示した.

7) PP 板で補剛された試験体の換算幅厚比に関して, 該当試験体の 座屈荷重と同等の座屈荷重を持つ無拘束パネルの換算幅厚比を等 価換算幅厚比として求めることを提案した.

8) 等価換算幅厚比と漸増載荷の載荷履歴を受ける試験体の終局時累 積塑性変形角に関係性があり，座屈により終局となる場合，等価 換算幅厚比が小さくなるほど，終局時累積塑性変形角が大きくな ることを示した。一方で, 亀裂により終局を迎える場合は, 終局 時累積塑性変形角は一定となるため, 終局状態が亀裂か座屈かの 境目となる等価換算幅厚比を釣合等価換算幅厚比として計算し, 


\section{それより等価換算幅厚比が小さい場合は終局時累積塑性変形角を}

一定とする評価方法を提案した.

9)座屈により終局に至った試験体の等価せん断座屈変形角と等価換 算幅厚比との間に，載荷履歴に依らず関係性があることを示し， 等価換算幅厚比による $\bar{\gamma}_{B} /{ }_{c a l} \gamma_{y}$ の評価式を示した.

ただし, 本論で検討した鋼板パネルは, アスペクト比 1.0 , パネル サイズ 176 330mm, 一般化幅厚比 1.25 ～ 3.57 であり, 本結論はこ の範囲の実験結果より得られたものである。他のアスペクト比の場 合や, より大きなサイズのせん断パネルの履歴性状の検証が今後の 課題として挙げられる.

\section{謝辞}

本研究は JSPS 科研費 $17 \mathrm{~K} 06643$ の助成を受けたものである. 本 研究の遂行においては, 神戸大学大学院生 (研究当時) ・三上紗綾氏, 胡弘宇氏, 藤井俊介氏, 佐々木公一氏, 朱華佳氏の多大な協力を得 た。ここに記して謝意を表します。

\section{参考文献}

1) The Japan Society of Seismic Isolation : The passive response control structure design construction manual third edition, pp.315-322, 2013.11 (in Japanese)

日本免震構造協会 : パッシブ制振構造設計・施工マニュアル第 3 版, pp.315-322, 2013.11

2) Tamai, H. et al. : On hysteretic damper using low yield stress steel plate installed in K-braced frame (Part 1, 2), Summaries of Technical Papers of Annual Meeting, Architectural Institute of Japan, C, Structures-II, pp.1447-1450, 1991.7 (in Japanese)

玉井宏章, 他 : 低降伏応力度鋼板を用いた $\mathrm{K}$ 型ブレース制振装置に関す る研究 (その 1,2 ), 日本建築学会大会学術講演梗概集, 構造 II, pp.1447$1450,1991.7$

3) Izumi, M. et al.: Low cycle fatigue tests on shear yielding type low yield stress steel hysteretic damper for response control (Part 1, 2), Summaries of Technical Papers of Annual Meeting, Architectural Institute of Japan, Structures-II, pp.1333-1336, 1992.7 (in Japanese) 泉満, 他: 極低降伏点鋼を用いたせん断降伏型制振部材の低サイクル疲 労実験 (その 1,2 ), 日本建築学会大会学術講演梗概集, 構造 II, pp.13331336, 1992.7

4) Tanaka, K. and Sasaki, Y.: Study on energy absorbing performance of seismic control panel-dampers using low-yield-point steel under static loading, Journal of Structural and Construction Engineering (Transactions of AIJ), No.509, pp.159-166, 1998.7(in Japanese) 田中清, 佐々木康人: 極低降伏点鋼を用いた制震パネルダンパーの静的 履歷減衰性能に関寸る研究, 日本建築学会構造系論文集, 第 509 号, pp.159-166, 1998.7

5) Tanaka, K. et al.: An experimental study on hysteretic performance of shear panel dampers using different strength type of steel under static loading, Journal of Structural and Construction Engineering (Transactions of AIJ), No.520, pp.117-124, 1999.6 (in Japanese) 田中清, 他 : 鋼種が異なるせん断型パネルダンパーの静的履歴特性に関 する実験研究, 日本建築学会構造系論文集, 第 520 号, pp.117-124, 1999.6

6) Kasai, K. and Popov, E.P. : General Behavior of WF Steel Shear Link Beams, Journal of Structural Engineering, ASCE, Vol.112, No.2, pp.362-382, 1986.2

7) Kasai, K. and Popov, E.P. : Cyclic Buckling Control for Shear Link Beams, Journal of Structural Engineering, ASCE, Vol.112, No.3, pp.505-523, 1986.3

8) Tamai, H.: On equivalent shear buckling deformation angle for shear panel damper, Journal of Structural and Construction Engineering (Transactions of AIJ), Vol.80 No.707, pp.137-145, 2015.1 (in Japanese) 玉井宏章 : せん断パネルダンパーの等価せん断座屈変形角について, 日
本建築学会構造系論文集，第 707 号，pp.137-145， 2015.1

9) Tamai, H. and Ogawa, K. : A design formula of shear panel damper Part 1 Equivalent Shear Buckling Limit Deformation Angle-, Hiroshima Univ. Bulletin research report, Vol.46, 139-148, 2012 (in Japanese)

玉井宏章, 尾川勝彦: せん断パネルダンパーの設計式に関する一考察 そ の 1 等価せん断座屈変形角, 広島工業大学紀要研究編第 46 巻, pp.139148, 2012

10) Zhu, H. : Hysteretic Property and Design Method of EnergyAbsorption Confined Steel Plates, Kobe University, Ph.D. thesis, 2014.1 (in Japanese)

朱華佳 : 補剛板で拘束された鋼製制振パネルの履歴特性と設計法に関す る研究, 神戸大学, 博士論文, 2014.1

11) Zhu, H. et al. : Hysteretic Properties of Confined Steel Panels, $10^{\text {th }}$ Japan-China Joint Conference on Structural Engineering, pp.930-935, 2013.11 (in Japanese)

朱華佳, 他 : 拘束鋼板耐力壁の履歴挙動に関する研究, 第 10 回日中建築 構造技術交流会論文集，pp.930-935，2013.11

12) Fujii, S. et al.: Effect of Aspect Ratio Hysteretic Properties of Confined Steel panels Part 1, Summaries of Technical Papers of Annual Meeting, Architectural Institute of Japan, Structures-III, pp.1163-1164, 2014.7 (in Japanese)

藤井俊介，他：アスペクト比が拘束鋼製制振パネルの履歴特性に及ぼす 影響に関する研究 (その 1), 日本建築学会大会学術講演梗概集, 構造III, pp.1163-1164, 2014.7

13) $\mathrm{Hu}, \mathrm{H}$. et al.: Effect of Thickness of the Restraining Plate on Hysteretic Properties of Confined Steel Panels, Summaries of Technical Papers of Annual Meeting, Architectural Institute of Japan, Structures-III, pp.1145-1146, 2015.7 (in Japanese)

胡弘宇，他：拘束鋼製せん断パネルの履歴特性に及ぼす拘束材厚さの影 響に関する研究，日本建築学会大会学術講演梗概集，構造III, pp.11451146, 2015.7

14) Mikami, S. et al.: Study on Hysteretic Properties of Confined Low Yield Strength Steel Panels (Part 1,2), Summaries of Technical Papers of Annual Meeting, Architectural Institute of Japan, Structures-III, pp.855-858, 2016.7 (in Japanese)

三上紗綾, 他 : 拘束低降伏点鋼せん断パネルの履歴特性に関する研究 (そ の 1,2$)$, 日本建築学会大会学術講演梗概集, 構造III, pp.855-858, 2016.7

15) Hitaka, T. et al.: Development of Slit Steel Baring Wall, Summaries of Technical Papers of Annual Meeting, Architectural Institute of Japan, Structures-III, pp.763-764, 1997.7 (in Japanese)

日高桃子, 他：スリット入り鋼板耐震壁の開発, 日本建築学会大会学術 講演梗概集，構造III，pp.763-764， 1997.7

16) Hitaka, T. et al.: Elastic-plastic behavior of steel bearing wall with slits, Journal of Structural and Construction Engineering (Transactions of AIJ), No.519, pp.111-117, 1999.5 (in Japanese) 日高桃子, 他：スリット入り鋼板耐震壁の弾塑性性状について, 日本建 築学会構造系論文集，第 519 号, pp.111-117, 1999.5

17) Sadakane, Y. et al.: Study on Methods for out-of-plane stiffening of the Steel Bearing Wall with Slits, Summaries of Technical Papers of Annual Meeting, Architectural Institute of Japan, Structures-III, pp.945-946, 2000.7 (in Japanese) 貞包佳秀，他：スリット入り鋼板而震壁の面外補剛法に関寸る研究，日 本建築学会大会学術講演梗概集, 構造III, pp.945-946, 2000.7

18) Ito, M. et al. : Design procedure for panels stiffening steel shear walls with slits, Journal of Structural and Construction Engineering (Transactions of AIJ), Vol.78, No.687, pp.987-995, 2013.5 (in Japanese)

伊藤麻衣，他：スリット入り鋼板耐震壁のパネル補剛設計式：日本建築 学会構造系論文集, 第 78 巻, 第 687 号, pp.987-995, 2013.5

19) Architectural Institute of Japan : Recommended Provisions for Seismic Damping Systems applied to Steel Structures, Maruzen, 2014.11 (in Japanese)

日本建築学会 : 鋼構造制振設計指針, 丸善, 2014.11

20) Timoshenko, S. and Gere, J.M.: Theory of Elastic Stability, Mcgraw Hill, 1961 


\section{STUDY ON ULTIMATE STRENGTH AND DEFORMATION CAPACITY OF CONFINED STEEL PANELS}

\section{Takashi TAKEUCHI ${ }^{* 1}$ and Yuping SUN ${ }^{* 2}$}

\footnotetext{
${ }^{* 1}$ Assist. Prof., Graduate School of Engineering, Kobe University, Dr.Eng.
}

*2 Prof., Graduate School of Engineering, Kobe University, Dr.Eng.

This paper investigated experimentally the hysteretic behavior of steel panels confined by two pieces of polypropylene plates (hereinafter referred to as PP plates) and bolts, and proposed methods to evaluate ultimate strength and deformation capacity of the confined steel panels. Thirty one $1 / 2$-scale and/or $1 / 4$-scale specimens were made and tested under reversed cyclical lateral loading, with the size, the thickness and the type of steel plates, the thickness of PP plates, and the loading program as main experimental variables.

Test results have indicated that when confined by PP plates thick enough to prevent the panel from out-of-plane buckling, the steel panels exhibited high lateral resistance and sound energy absorption performance until the drift angle of 0.07 rad without resistance degradation. For the bare steel panels and those confined by thin PP plates, out-ofplane buckling occurred before the drift level of $0.05 \mathrm{rad}$, but the deformation capacity increased along with the thicknesses of steel plates and PP plates. The specimen having sufficient confinement cracked at the corners of the steel panel at large drift beyond $0.07 \mathrm{rad}$, and the deformation capacity was independent of the thickness of PP plates. Test results also shown that the loading history might affect the cumulative plastic drift angle at the ultimate state.

The full plastic moment of the plate section can predict ultimate strength of the steel panels confined by PP plates with sufficient thickness on the safe side, and increasing the yield strength of steels by 10 percent to take into account the effect of strain hardening can enhance accuracy of the theoretical ultimate strength. An equation based on the elastic lateral buckling strength of the steel-PP composite plate was proposed to predict the lateral buckling load of the confined panel without sufficient confinement by PP plates, and gave very good prediction of the measured buckling loads. It is noteworthy that one can determine the minimum thickness of PP plates to prevent the panel from the premature out-of-plane buckling just by letting the lateral resistance (cal $\mathrm{Qbu}_{\text {bu }}$ ), defined by Eq. (3), corresponding to the 10\% enhanced full plastic moment, be smaller than the calculated buckling load (cal Q $\mathrm{cr}_{2}$ ), defined by Eq. (10).

Furthermore, the equivalently converted width-thickness ratio $\left((\mathrm{b} / \mathrm{t})_{\mathrm{BE}}\right.$, see Eq. $\left.(14)\right)$ and the balanced $(\mathrm{b} / \mathrm{t})_{\mathrm{BE}}\left(=_{\mathrm{eq}}(\mathrm{b} / \mathrm{t})\right.$ BE, see Eq. (16)) were introduced to evaluate the ultimate accumulative plastic drift angles $\left(\gamma_{\mathrm{u}}\right)$ and the equivalent shear buckling deformation angle $\left(\gamma_{\mathrm{B}}\right)$ of the confined steel panels. Very strong correlations existed between the measured drift angles at ultimate states and the theoretical ones calculated by Eq. (15) and Eq. (20), respectively. The cumulative plastic drift angles at ultimate states of the specimens failing in out-of-plane buckling increased with the decrease of the $(d / t)_{B E}$, while those of the specimens failing with crack at the corners of steel plates were almost constant. These observations imply the rationality of the introduced two terms $\left((\mathrm{b} / \mathrm{t})_{\mathrm{BE}} \text { and } \mathrm{eq}(\mathrm{b} / \mathrm{t})_{\mathrm{BE}}\right)_{\text {and }}$ the accuracies of the empirical formulae (Eq. (15) and Eq. (20)). 